\title{
A functional mRNA polyadenylation signal is required for transcription termination by RNA polymerase II
}

\author{
Sheila Connelly and James L. Manley \\ Department of Biological Sciences, Columbia University, New York, New York 10027 USA
}

\begin{abstract}
Polyadenylation of pre-mRNAs requires the conserved hexanucleotide AAUAAA, as well as sequences located downstream from the poly(A) addition site. The role of these sequences in the production of functional mRNAs was studied by analyzing a series of mutants containing deletions or substitutions in the SV40 early region poly(A) site. As expected, both a previously defined GU-rich downstream element and an AAUAAA sequence were required for efficient usage of the wild-type poly(A) addition site. However, when either of these elements was deleted, greatly increased levels of SV40-specific RNA were detected in the nuclei of transfected cells. Evidence is presented that this accumulation of RNA resulted from a failure of transcription termination, leading to multiple rounds of transcription of the circular templates. We conclude that the sequences required for efficient cleavage/polyadenylation of the SV40 early pre-mRNA also constitute an important element of an RNA polymerase II termination signal. A model proposing a mechanism by which the act of pre-mRNA 3' end formation is signaled to the elongating RNA polymerase, resulting in termination, is presented.
\end{abstract}

[Key Words: mRNA; polyadenylation signal; polymerase II; transcription]

Received February 2, 1988; revised version accepted March 7, 1988.

Eukaryotic mRNAs have unique structural features, one of which is a poly(A) segment at the $3^{\prime}$ end of the molecule. Unlike prokaryotic mRNAs, the $3^{\prime}$ ends of which are formed primarily by termination events, higher eukaryotic mRNA $3^{\prime}$ ends are formed by endonucleolytic cleavage and subsequent polyadenylation, with transcription continuing beyond the poly(A) site (for review, see Birnstiel et al. 1985). Much has been learned recently about the specific signals that control $3^{\prime}$ end formation of mRNA molecules. The poly(A) site has been shown to contain at least three sequence elements. The most highly conserved is the hexanucleotide AAUAAA, found 10 to 30 nucleotides upstream from the $3^{\prime}$ end of the vast majority of polyadenylated mRNAs (Proudfoot and Brownlee 1976; for a recent compilation, see Berget 1984). This sequence has been shown to be essential for proper $3^{\prime}$ end formation in vivo (Fitzgerald and Shenk 1981; Higgs et al. 1983; Montell et al. 1983; Wickens and Stephenson 1984) and for both cleavage and polyadenylation in vitro (Manley et al. 1985; Moore et al. 1986; Zarkower et al. 1986). The second element, the poly $(A)$ addition site itself, is a dinucleotide, the second nucleotide of which is invariably an adenosine residue (Fitzgerald and Shenk 1981; McLauchlan et al. 1985; Mason et al. 1986). Cleavage occurs $3^{\prime}$ to the adenosine residue, and the poly(A) tail is constructed by the addition of single adenosine residues until a final length of 200-300 nucleotides is reached (Moore et al. 1986; Sheets et al. 1987). The final element so far defined, the downstream element, is less conserved than the AAUAAA sequence, and it appears that there are at least two distinct types of downstream elements (McDevitt et al. 1986). One type, a GU-rich sequence, is present, e.g., in the SV40 early gene poly(A) site, whereas the other, a U-rich sequence, is exemplified by the SV40 late gene poly $(\mathrm{A})$ site. Disruption of these elements results in a decreased usage of the respective poly(A) sites by 75-90\% (Hart et al. 1985; Sadofsky et al. 1985). These downstream elements are, therefore, not absolutely required for polyadenylation, and may serve to modulate the efficiency of usage of poly(A) sites.

Contrasting with what is known about eukaryotic mRNA 3 '-end formation, very little is known about signals that control transcription termination by RNA polymerase II in higher eukaryotes. Transcription continues beyond the poly(A) site in both viral (Ford and Hsu 1978; Nevins and Darnell 1978/ and cellular genes (Weintraub et al. 1981; Hofer et al. 1982; Amara et al. 1984; Mather et al. 1984; Sheffey et al. 1984), terminating as much as several kilobases downstream from the poly(A) site (Citron et al. 1984; Frayne et al. 1984; Hagenbuchle et al. 1984; LeMeur et al. 1984). Recent studies have raised the possibility that termination by RNA polymerase II occurs only after encountering a functional poly(A) site. For example, the proposed mouse major $\beta$-globin transcription termination element, located within a region 600-1500 nucleotides downstream of the globin poly(A) site (Citron et al. 
1984), was not functional in terminating transcription when an 800-bp DNA fragment, located upstream of this region and including the poly(A) site, was removed (Falck-Pedersen et al. 1985). More recently, point mutations in the AATAAA sequence within this fragment were shown to inhibit polyadenylation and to result in increased transcription through this termination region (Logan et al. 1987). In addition, a thalassemic $\alpha-2$ globin gene that contains a point mutation changing the conserved AATAAA sequence to AATAAG (Higgs et al. 1983) failed to produce mRNA polyadenylated at the normal site and also gave rise to higher levels of RNA transcribed from sequences downstream of the poly(A) addition site (Whitelaw and Proudfoot 1986). Finally, Acheson (1984) noted a correlation between inefficient polyadenylation and inefficient termination in the polyoma virus late transcription unit.

The data presented here provides direct evidence that a functional poly(A) addition signal is a crucial element of an RNA polymerase II termination signal. We used transient expression assays to analyze RNA produced from mutants containing deletions in the SV40 early polyadenylation signal region and found that both the GTrich downstream element and the AATAAA conserved sequence are required for transcription termination by RNA polymerase II.

\section{Results}

Efficient production of SV40 early $m R N A$ requires two sequence elements

The role of conserved sequences in the formation of SV40 early polyadenylated cytoplasmic mRNA was studied by analyzing the mRNAs produced from a series of deletion mutants in transient expression assays. Details of the wild-type plasmid, p $\phi 4-S V A$, which contains the adenovirus major late promoter controlling expression of the SV40 early region, and many of the deletion mutants have been described previously (Manley et al.
1985). A diagram of p $\phi 4-S V A$, the poly(A) site nucleotide sequence, and a map of the deletion endpoints is shown in Figure 1. Transient expression assays were performed in 293 cells, which are human embryonic kidney cells transformed by adenovirus type-5 DNA and which constitutively express the adenovirus E1A and E1B genes (Graham et al. 1977; Aiello et al. 1979). Previous studies have shown that high levels of expression from the adenovirus type-2 (Ad2) major late promoter could be detected when plasmids such as $\mathrm{p} \phi 4$-SVA were assayed in these cells (Lewis and Manley 1985). The plasmid pSV2.CAT (Gorman et al. 1982) was included in all assays to standardize transfection efficiencies (see Materials and methods).

Cytoplasmic RNA was isolated from 293 cells transfected with each of the deletion mutants or with the wild-type plasmid. The RNA was separated into poly $(\mathrm{A})^{+}$and poly $(\mathrm{A})^{-}$fractions by oligo $(\mathrm{dT})$-cellulose chromatography and analyzed by nuclease S1 analysis using a DNA probe derived from the wild-type plasmid. With this probe, RNAs cleaved at the wild-type poly|A) addition site generate a 230-nucleotide protected DNA fragment. Figure 2 displays the results of such an experiment and indicates that the wild-type plasmid and mutant 6 generated a product of the expected size. Mutant 6 retains 19 nucleotides downstream from the poly(A) site, and as reported previously (Hart et al. 1985), this is sufficient for efficient cleavage and polyadenylation at the wild-type site. However, with the deletion of another 8 nucleotides (mutant 12), the appearance of mRNA cleaved at the wild-type site was reduced significantly, although an equal amount of RNA cleaved and polyadenylated at an upstream cryptic site, giving rise to a protected fragment of 198 nucleotides, was detected. 3 '-end formation at this site was directed by an upstream AAUAAA sequence (see below and Fig. 1). With the deletion of another 5 bases (mutant 15), usage of the wildtype site was reduced further, and a slightly increased amount of mRNA cleaved at the cryptic site was detected. The total amount of mRNA produced by mu-

A

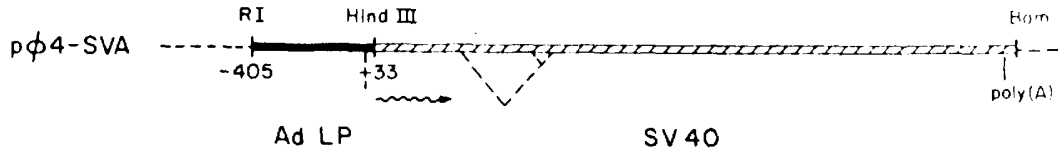

B

\section{SVAO EARLY REGION POLYIAI SITE MUTANTS}

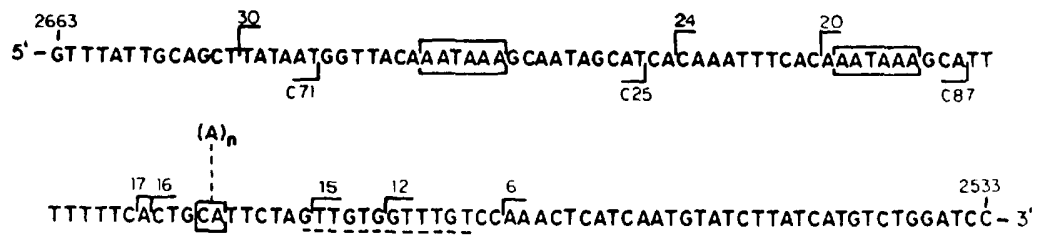

Figure 1. Structure of p $\phi 4-S V A$ and deletion mutants. (A) Plasmid p $\phi 4-S V A$ contains 438 bp of Ad2 DNA, extending from -405 to +33 , relative to the transcription start site of the major late transcript at +1 , denoted by the heavy line. The SV40 T-antigen-encoding sequences extend from the SV40 HindIII site at nucleotide 5171 to the SV40 BamHI site at nucleotide 2533 and are indicated by the hatched line. $(B)$ The nucleotide sequence of the $3^{\prime}$ - end of the SV40 T-antigen gene, from nucleotide 2663 to the BamHI site at 2533 (Tooze 1981). The two copies of the conserved hexanucleotide, AATAAA, are boxed, as is the poly(A) addition site. The GT-rich poly(A) site downstream element is indicated by a dotted line. The endpoints of the deletions are denoted by half-brackets. 


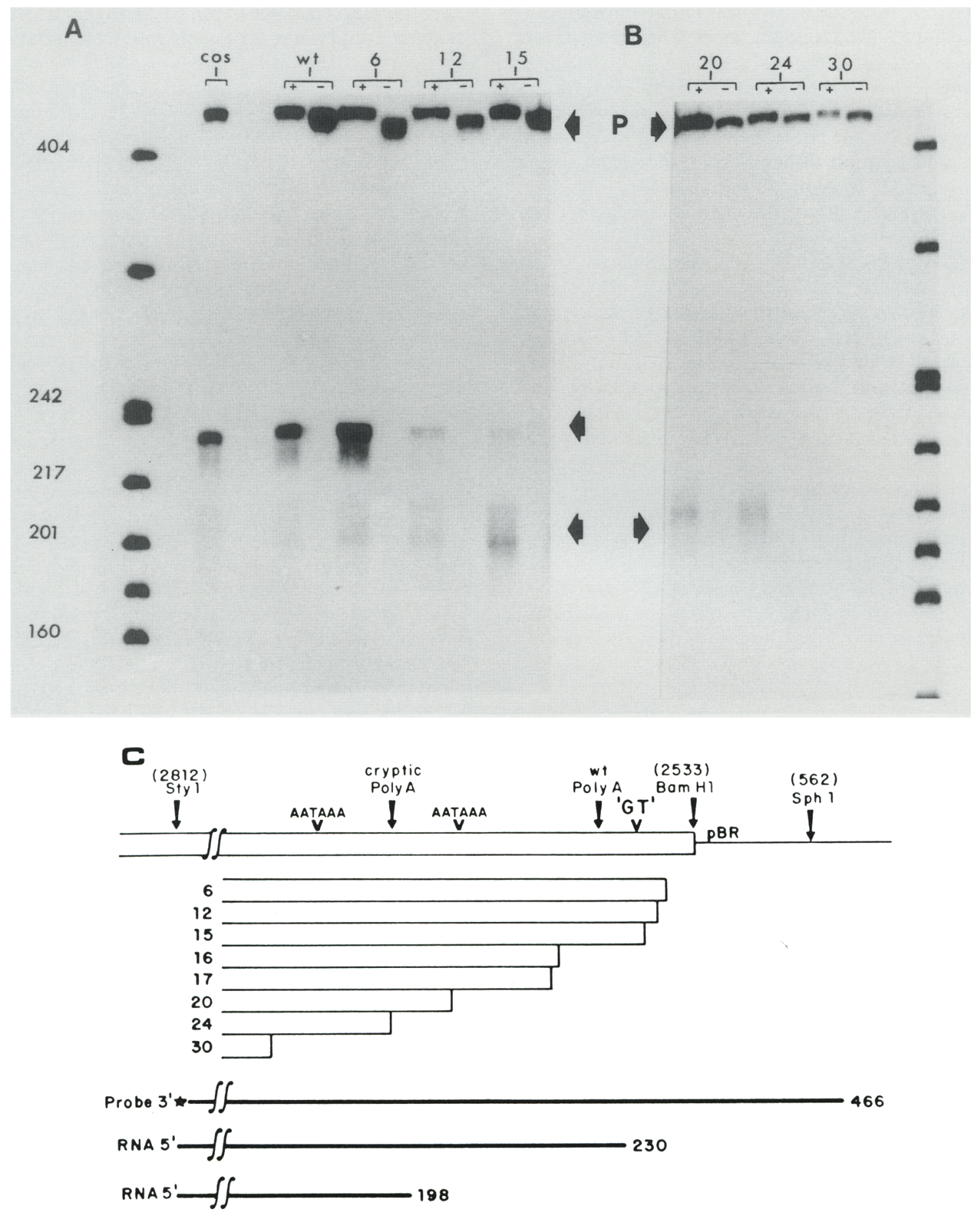

Figure 2. Effects of SV40 early region poly(A) site deletions on the generation of polyadenylated cytoplasmic mRNA. 293 cells were transfected with p $\phi 4$-SVA or mutant plasmids plus pSV2.CAT (see Materials and methods). Cytoplasmic RNA was extracted 48 hr later, selected on oligo(dT)-cellulose, and analyzed by nuclease S1 protection and polyacrylamide gel electrophoresis, as described in Materials and methods. The 3'-end-labeled DNA probe used was derived from p $\phi 4$-SVA, extending from the SV40 StyI site (nucleotide $2812)$ to the pBR322 SphI site. The plasmids used for transfection are indicated at the top of $A$; wt corresponds to p $\phi 4$-SVA and the mutants are listed by number. The + and - symbols indicate that poly $(\mathrm{A})^{+}$and poly $(\mathrm{A})^{-}$RNA fractions were used in S1 analysis. Arrows mark the nuclease S1-protected fragments. (P) Undigested probe, equal amounts of which were produced by RNA samples from cells that were not transfected. Size marker is pBR322 DNA digested with HpaIl and 5'-end labeled; sizes (in nucleotides) are indicated on the left. The lane labeled Cos contained total cytoplasmic RNA from Cos cells, an SV40-transformed monkey cell line (Gluzman 1981), as a marker for accurate polyadenylation. ( $A$ and $B$ ) The results of separate transfections. (C) A schematic diagram of the deletions relative to the wild-type plasmid consensus sequences and poly $(\mathrm{A})$ addition site. The structure of the probe and nuclease S1 digestion products are indicated. 
tants 12 and 15, polyadenylated at either the wild-type or cryptic poly(A) site, was reduced to approximately one-third the amount produced by the wild-type plasmid or mutant 6 . When both AATAAA sequences were deleted, as with mutant 30 , no cytoplasmic RNA was detected.

Several mutants that extended into the region encoding the poly $(\mathrm{A})$ signal sequences from the $5^{\prime}$ side (Manley et al. 1985; see Fig. 1) were also studied by transient expression and nuclease S1 analysis. The results of this analysis (not shown) indicate that a deletion mutant retaining both AATAAA sequences $[C 71$; see Fig. 1) produced high levels of mRNA polyadenylated at the wildtype site, as did a mutant lacking the $5^{\prime}$ AATAAA sequence (C25; see also Fig. $4 \mathrm{~B})$, suggesting that sequences upstream of the AATAAA are not necessary for mRNA 3 '-end formation, as reported previously (Kessler et al. 1986). However, as expected, a mutant lacking both AATAAA consensus sequences (C87) did not produce any SV40-specific cytoplasmic RNA.

\section{Mutants that disrupt the poly(A) site downstream element accumulate high levels of nuclear RNA}

To analyze further the role of the AAUAAA sequence and the downstream element on mRNA 3 '-end formation, nuclear RNA was isolated from 293 cells transfected with the wild-type and mutant plasmids and analyzed by nuclease S1 analysis (Fig. 3). The protected fragment corresponding to RNA processed at the wild-type site was again 230 nucleotides, as seen with samples obtained from p $\phi 4-S V A$ and mutant-6-transfected cells, The larger protected fragments represent unprocessed RNA, the sizes of which are dependent on the endpoint of the deletion in each plasmid, i.e., the point at which transcript and DNA probe are no longer homologous. Unexpectedly, there was a substantial accumulation of nuclear RNA in cells transfected with the mutants that disrupt or delete the GT-rich region. As judged by densitometer scanning, 12- to 20-fold more nuclear RNA was produced in cells transfected with mutant plasmids than in wild-type or mutant-6-transfected cells. A lighter exposure of the gel shown in Figure 3 (not shown) reveals that most of this accumulated RNA was not $3^{\prime}$ end processed. This accumulation of nuclear RNA was not an artifact due to contamination of the RNA samples with transfected DNA. All samples had been treated with DNase I before nuclease S1 analysis, and treatment of the samples with RNase A before nuclease S1 analysis abolished all signals (data not shown).

To determine whether plasmids that retain the GTrich region-but delete either one or both of the AATAAA sequences - also result in accumulation of nuclear RNA, several additional mutants were analyzed. Mutant LS contains a substitution that disrupts only the $3^{\prime}$ AATAAA sequence (see Materials and methods). Figure 4A shows the results of nuclease $S 1$ analysis of RNA isolated from wild-type, mutant $15-$, and mutant LS - transfected cells. Analysis of cytoplasmic RNA revealed that the cryptic poly $(A)$ site described above was used exclusively by mutant LS, whereas mutant 15 showed approximately equal utilization of both the wild-type and cryptic sites. The amount of mRNA pro-

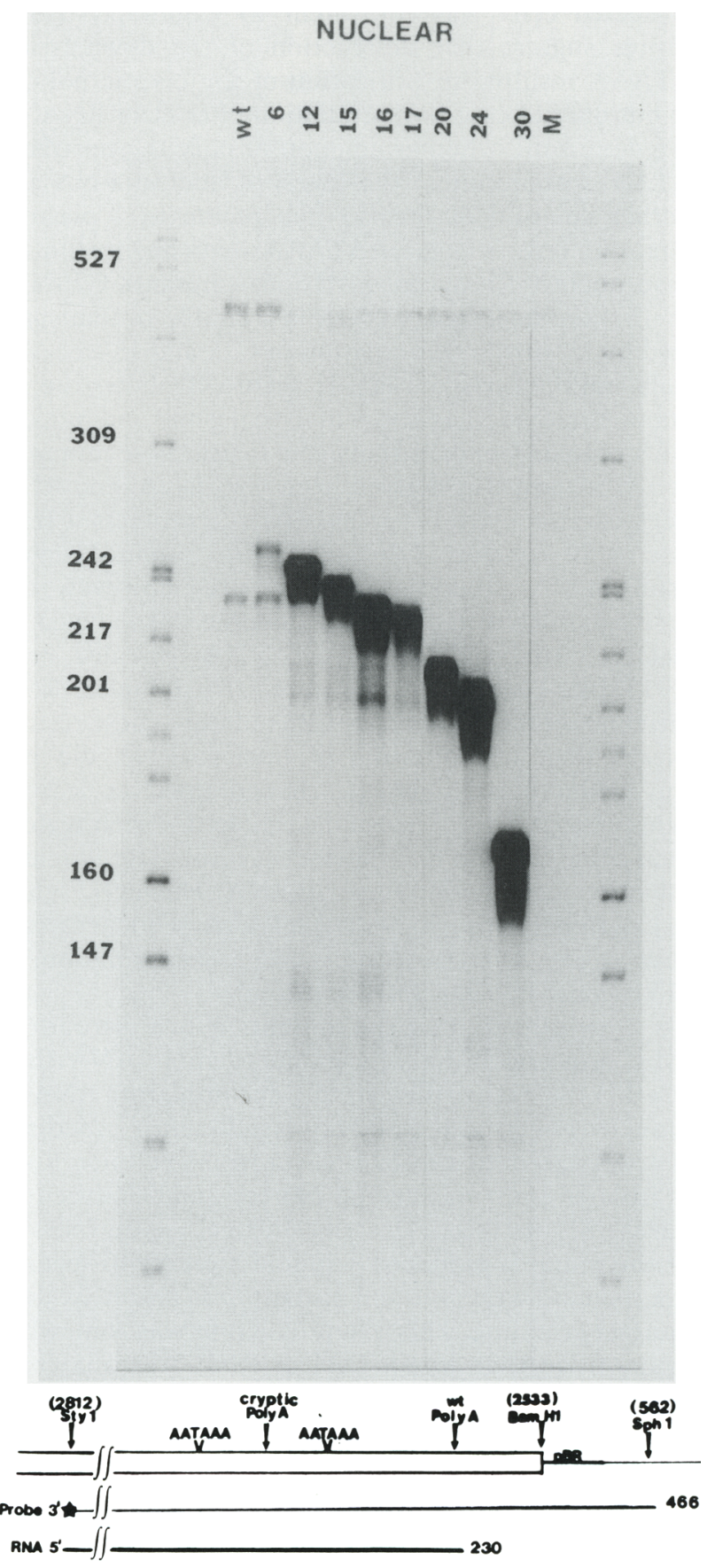

Figure 3. Effects of deletions on the levels of SV40-specific nuclear RNA. Nuclear RNA was isolated from cells transfected with the indicated deletion mutants plus pSV2.CAT and treated with DNase I. Nuclease S1 analysis was done exactly as described in Fig. 2. The plasmids used for transfection are indicated at the top. Lane $M$ utilized nuclear RNA from cells that had not been transfected in nuclease S1 analysis. (Bottom) The schematic diagram shows the probe and nuclease S1 digestion products relative to wild-type plasmid sequences. 
duced by LS was equivalent to wild type, whereas, mutant 15 mRNA levels were significantly reduced, as above. However, although a 15-fold increased accumulation of nuclear RNA was again observed in mutant 15transfected cells, the amount of nuclear RNA in LStransfected cells was equivalent to wild type. These findings suggest that destruction of the downstream AATAAA resulted in utilization of the cryptic poly(A) site but did not cause accumulation of nuclear RNA.

To determine whether deletion of only the upstream AATAAA would affect the levels of nuclear RNA and whether deletion of the GT-rich region in a plasmid containing only a single AATAAA sequence would increase nuclear RNA concentrations, mutants C25 and C25-15 were analyzed. C25-15 is a double mutant produced by in vitro recombination of $\mathrm{C} 25$ and 15 (see Materials and methods and Fig. 1). Figure 4B shows the results of nuclease S1 analysis of cytoplasmic and nuclear RNA isolated from cells transfected with these mutants. The probe used was derived from C25 DNA, and RNA processed at the wild-type poly(A) site protects a fragment of 89 bp. Both C25 and C25-15 produced cytoplasmic RNA processed at this site; however, the amount of mRNA in the C25-15 sample was reduced, as expected. Analysis of nuclear RNA revealed that C25-15, like 15, accumulated unprocessed nuclear RNA relative to wild type but that $\mathrm{C} 25$ did not. These results indicate that accumulation of nuclear RNA did not occur when plasmid templates contained at least a single AATAAA sequence and an intact GT-rich region, which coincide with the sequences required for efficient production of polyadenylated mRNA. However, when the GT-rich region or both AATAAA sequences (see below) were deleted, a substantial accumulation of SV40-specific nuclear RNA occurred.

To show directly that the mutants which disrupt the poly(A) site region actually produced more RNA than the wild type, rather than simply accumulating RNA in the nucleus because it could not be efficiently processed and transported to the cytoplasm, total cellular RNA was isolated from transfected 293 cells and analyzed by nuclease $\mathrm{SI}$ analysis as described above. Figure 5 shows that the mutants produced $\sim 10$-fold more SV40-specific RNA than did wild type and mutant 6 , as judged by densitometer scanning. This overproduction was somewhat less dramatic than when nuclear RNA was analyzed, presumably because reduced amounts of cytoplasmic RNA were present in mutant-transfected cells, as shown in Figures 2 and 3. Therefore, the poly(A) site region is involved in negatively regulating RNA accumulation, rather than being solely involved in nuclear transport.

\section{The GT-rich downstream element and the AATAAA sequence act together as an RNA polymerase II termination signal}

How does deletion of the poly(A) signal sequences result in overproduction of SV40 RNA? Three possibilities can be suggested. First, the mutations could result in increased levels of transcription initiation, with the RNA retained primarily in the nucleus because of inefficient 3 '-end processing. Second, the mutations might render the RNA more stable in the nucleus, again perhaps because of its failure to be polyadenylated efficiently. Finally, transcription termination might be impaired by poly(A) site mutations, resulting in multiple rounds of transcription of the circular templates and, thus, the observed accumulation of SV40-specific RNA. The following experiments provide strong support for this last possibility.

To test whether increased levels of transcription were brought about by the poly(A) site mutations, nuclease S1 analysis of the $5^{\prime}$ ends of nuclear RNAs from wild-type and mutant-transfected cells was performed. Nuclear or total cellular RNA was hybridized to a probe prepared from an Ad2 major late promoter (MLP) deletion mutant, p601-SVA, which lacks sequences between -60 and -405 (Lewis and Manley 1985). This DNA fragment was selected to distinguish between undigested probe (500-nucleotide protected fragment), RNA initiated at +1 in the MLP (118-nucleotide protected fragment), and RNA that had initiated upstream of the MLP (178-nucleotide protected fragment), in which case the protected fragment corresponds to the point at which the probe and RNA diverge, position -60 in the MLP. We assume that such 'read-through' RNA reflects transcription that had initiated at the MLP and continued entirely around the circular plasmid. Evidence supporting this view is presented below. As shown in Figure 6A, in both nuclear and whole-cell RNA samples, the amounts of RNA initiated at +1 (118-nucleotide band) were similar in the wild-type and mutant RNAs. However, substantially increased amounts of read-through RNA (178-nucleotide band) were observed in the overproducing mutants compared with the wild-type and mutant- 6 samples. The increase in the intensity of the full-length probe band 1500 nucleotides) in the mutant samples probably also results from read-through RNA, because it is likely that nuclease $S 1$ did not quantitatively cleave the DNA at the site in the RNA-DNA hybrid opposite the RNA loop. Nuclease S1 analysis of the $5^{\prime}$ ends of nuclear RNA obtained from cells transfected with $5^{\prime}$-deletion mutants $\mathrm{C} 71$ and $\mathrm{C} 87$ is shown in Figure 6B. Mutant C87, which deletes both AATAAA sequences, gave rise to an increased level of read-through RNA (178-nucleotide band) compared with $\mathrm{C} 71$ or wild type. These results, taken together, indicate that deletion of either both AATAAA sequences or the GT-rich region results in an increased amount of read-through RNA and support the idea that neither of these sequence elements influences the levels of transcription initiation.

The next set of experiments was undertaken to test whether the large accumulation of SV40-specific nuclear RNA found in mutant-transfected cells was due to increased levels of transcription or to increased stability of the mutant transcripts. To distinguish between these possibilities, nuclei were isolated from transfected 293 cells and nascent RNA chains were elongated in the presence of $\left[\alpha^{-32} \mathrm{P}\right]$ GTP (Salditt-Georgieff et al. 1984). Under these conditions, transcription initiation does not 

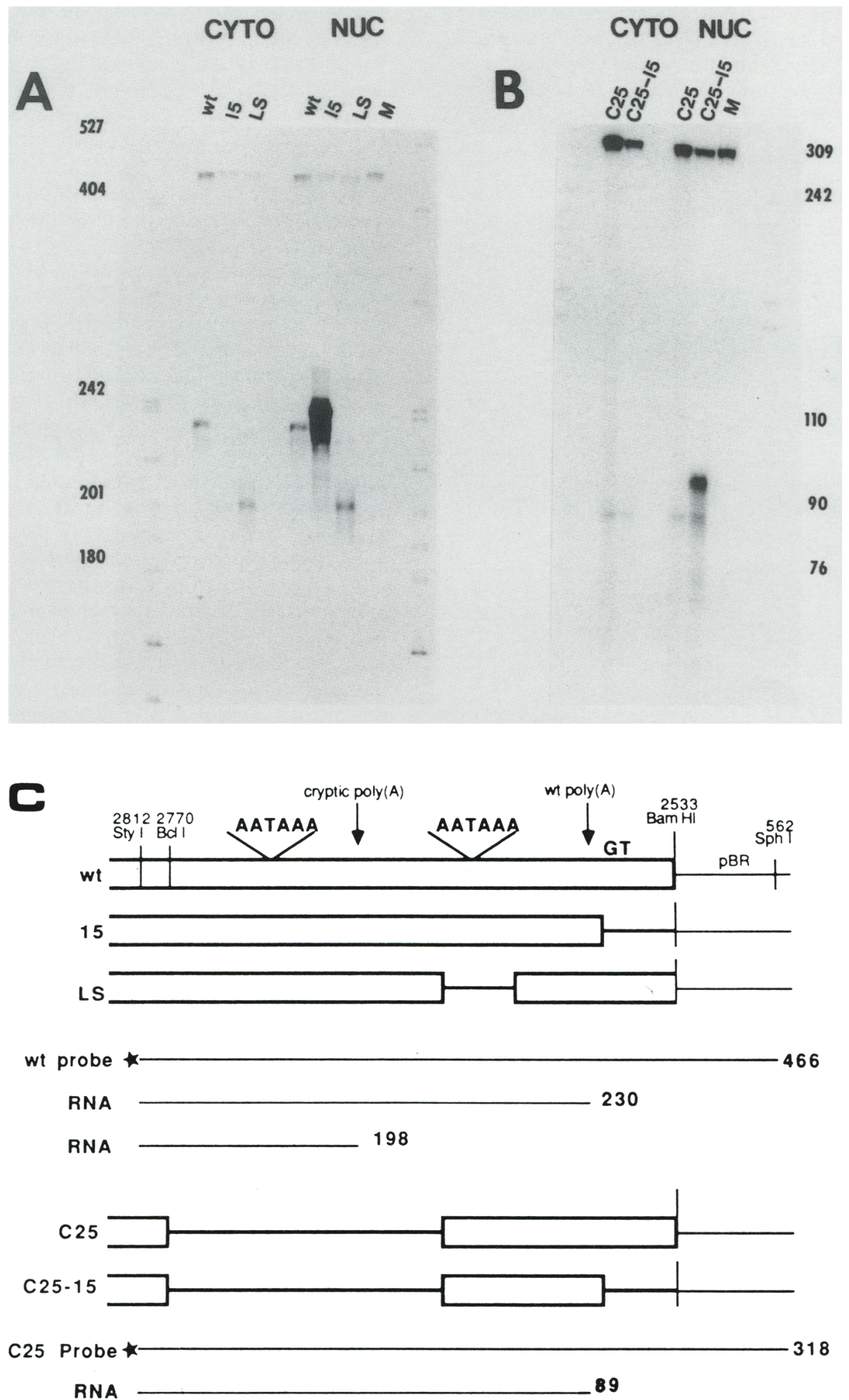

Figure 4. Comparison of cytoplasmic and nuclear RNAs from cells transfected with poly(A) site deletion and substitution mutants. Cytoplasmic (cyto) and nuclear (nuc) RNAs isolated from transfected cells were subjected to nuclease S1 analysis. (A) Comparison of cytoplasmic and nuclear RNA levels in p $\phi 4$-SVA (wt), mutant-15, or mutant-LS-transfected cells, using the $3^{\prime}$-end-labeled p $\phi 4$-SVA DNA probe described in Fig. 2. (B) Nuclease S1 analysis of cytoplasmic and nuclear RNAs isolated from C25- or C25-15-transfected cells using a probe prepared from C25 DNA. (C) The probe, nuclease S1 digestion products, and mutant 15, LS, C25, and C25-15 sequences relative to $\mathrm{p} \phi 4-\mathrm{SVA}$. 
occur, and preinitiated RNA chains are elongated by 100-300 nucleotides (Weber et al. 1977). This assay is therefore a measure of the number of polymerase molecules actively transcribing the DNA template at the time of nuclei isolation. If transcription termination was

\section{WHOLE CELL RNA}
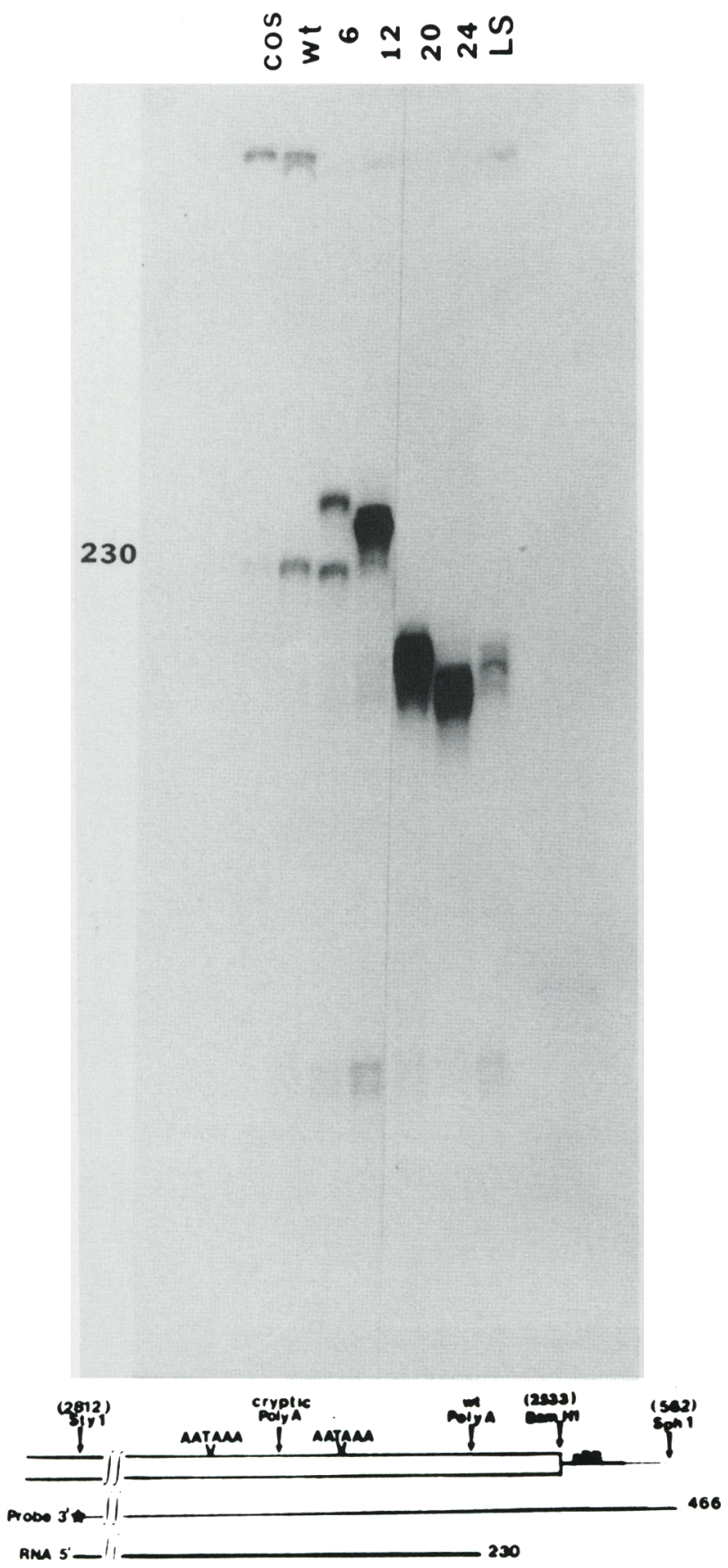

Figure 5. Quantitation of SV40-specific RNA in whole-cell RNA samples. Whole-cell RNA was isolated from cells transfected with p $\phi 4$-SVA (wt) and the deletion mutants indicated at the top and analyzed by nuclease $\mathrm{Sl}$ as in Figure 2. Lane cos utilized total cytoplasmic RNA isolated from Cos cells in the nuclease S1 reaction. (Bottom) The probe and nuclease S1 digestion products relative to $\mathrm{p} \phi 4-\mathrm{SVA}$. disrupted, we would expect a mutant plasmid to have a higher density of RNA polymerase molecules than the wild-type template, leading to increased synthesis in the isolated nuclei. Alternatively, if the mutant RNA was simply not degraded, the number of polymerases on the two templates should be equivalent, and the amount of RNA synthesized in isolated nuclei would be similar. RNA extracted from nuclei was analyzed by hybridization to DNA fragments bound to nitrocellulose /slot blots|, and the results are shown in Figure 7. Between six- and ninefold more labeled RNA was synthesized in nuclei isolated from mutant-C25-15, 15, C87, and 30transfected cells than from wild-type or wild-type-like mutants C25 and LS. This labeled RNA was a product of RNA polymerase II transcription, as the addition of $\alpha$ amanitin $(1 \mu \mathrm{g} / \mathrm{ml})$ to reaction mixtures blocked its appearance (data not shown). With both wild-type and mutant samples, the RNA hybridized to p $\phi 4$-SVA and pBR322 DNAs, consistent with the idea that transcription extended through the pBR322 sequences even in p $\phi$ 4-SVA.

To show that the transcription detected in the isolated nuclei was authentic, i.e., initiated from the $\mathrm{Ad} 2$ late promoter and not from artifactual sites elsewhere in the plasmid, and at the same time to rule out the possibility that deletion of the poly $(A)$ signal sequences resulted in a high level of random transcription initiation downstream of the poly(A) site, RNA synthesized in nuclei isolated from cells transfected with p601-SVA $\Delta 30$ was analyzed. p601-SVA is a deletion mutant of the late promoter that lacks sequences upstream of -60 and has been shown to be transcribed very inefficiently in 293 cells (Lewis and Manley 1985). p601-SVA $\Delta 30$ is a derivative of p601-SVA that contains the deleted poly(A) site of mutant 30 (Fig. 1), thereby removing both the AATAAA and GT-rich sequence elements. If the transcription detected in the above experiments initiated from the MLP, nuclei isolated from p601-SVA $\Delta 30$-transfected cells should synthesize greatly reduced amounts of specific RNA relative to mutant-30-transfected cell nuclei. The results shown in Figure 7 indicate that nuclei isolated from cells transfected with p601-SVA $\Delta 30$ produced very little, if any, SV40- or pBR322-specific RNA. In an additional control experiment, labeled RNA isolated from the nuclei of wild-type or mutant-30transfected cells was hybridized to both the antisense and sense DNA strands present in an Ml3 clone containing the SV40 HindIII B fragment (Noble et al. 1986), which extends from SV40 nucleotides 4002-5171. The labeled RNA hybridized exclusively to the antisense DNA strand (data not shown), providing further support for the specificity of the transcription observed. These findings suggest that random transcription initiation did not occur and that the RNA analyzed in these experiments had indeed initiated from the MLP.

The results of the nuclear transcription experiments indicate that the plasmid templates in the nuclei of cells transfected with the overproducing mutants contained much higher densities of RNA polymerase molecules than did wild-type templates. Because the amount of ini- 


\section{3’DELETION MUTANTS}

A

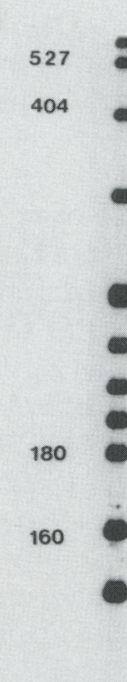

122

110

NUCLEAR

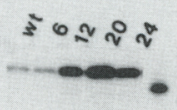

B

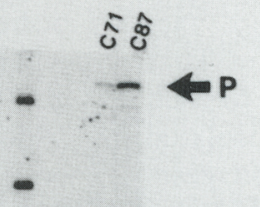

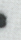

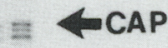

-

WHOLE CELL

NUCLEAR

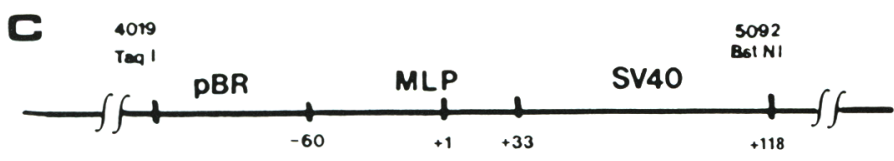

Probe

- 50

Initiated

$m^{7} G_{p p}$

Read Through

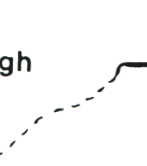

tiation appeared similar in all samples (Fig. 6), we conclude that this arose from a failure of transcription termination and that one of the two AATAAA consensus sequences and the GT-rich downstream element are both necessary and function together to form at least part of an RNA polymerase II termination signal.

\section{Discussion}

Our data provide evidence that the same sequences required for efficient polyadenylation of SV40 early mRNA are also required for transcription termination. Deletion mutations that reduced the efficiency of polyadenylation resulted in a dramatic accumulation of SV40-specific RNA in the nuclei of transfected cells, and several experiments indicate that this was due to multiple rounds of transcription of the circular plasmids. That this RNA was found only in the nucleus could indicate that cleavage/polyadenylation is required for nu-
Figure 6. Analysis of the $5^{\prime}$-ends of nuclear and whole-cell RNA synthesized from p $\phi 4-S V A$ and deletion mutants. Nuclear or whole-cell RNA was isolated from cells transfected with p $\phi 4-$ SVA (wt) or deletion mutant plasmids and analyzed by nuclease $\mathrm{S} 1$ protection, as described in Materials and methods. The probe was a 5 '-endlabeled 500-bp TaqI-BstNI fragment of p601SVA. p601-SVA is identical to p $\phi 4-S V A$, except that p601-SVA contains a 345-bp deletion in the adenoviral sequences (nucleotides -405 to -60 ). (CAP) The 118-nucleotide nuclease-S1protected fragment, corresponding to RNA initiated at +1 in the MLP; (RT) the 178-nucleotide nuclease-S1-protected DNA, which corresponds to read-through RNA; $(\mathrm{P})$ the undigested, fulllength probe. (A) Nuclease SI analysis of nuclear or whole-cell RNA isolated from $3^{\prime}$-deletion mutant transfected cells, as indicated. $(B)$ Nuclease $\mathrm{S} 1$ analysis of nuclear RNA isolated from $5{ }^{\prime}$-deletion mutant transfected cells, as indicated. $(C)$ The probe and nuclease-S1-resistant fragments relative to p601-SVA DNA. clear-cytoplasmic transport or that these RNAs were not released from transcription complexes.

We have not determined the site(s) at which termination actually occurred during transcription of the wildtype plasmid. It appears, however, not to be at the poly(A) addition site itself. Nuclear run-on transcription experiments revealed roughly equal transcription of fragments upstream and downstream of the cleavage/polyadenylation site (Fig. 6; S. Connelly, unpubl.), which would not have been observed had termination occurred at the $3^{\prime}$ end of the gene. Similar findings have been observed in many other systems (e.g., Ford and Hsu 1978; Nevins and Darnell 1978; Weintraub et al. 1981; Hofer et al. 1982; Amara et al. 1984; Frayne et al. 1984; Mather et al. 1984; Sheffey et al. 1984). Additionally, 5'-end analysis of nuclear RNA extracted from wild-type transfected cells (Fig. 6) revealed approximately equal quantities of RNA initiated at the $\mathrm{Ad} 2$ late promoter and read-through RNA which, our evidence indicates, con- 
sists of molecules extending entirely around the circular templates. Together, these two findings suggest that each RNA polymerase II molecule traverses the entire wild-type plasmid on average about one time.

Where might transcription normally terminate? That approximately equal levels of RNA hybridizing to each segment of pBR322 were synthesized in nuclei isolated from transfected (S. Connelly, unpubl.) cells suggests that there is not a specific termination site in these sequences. Indeed, it is not clear whether termination occurs at a unique site, at heterogeneous sites that are confined to a particular region, or at sites that are essen-

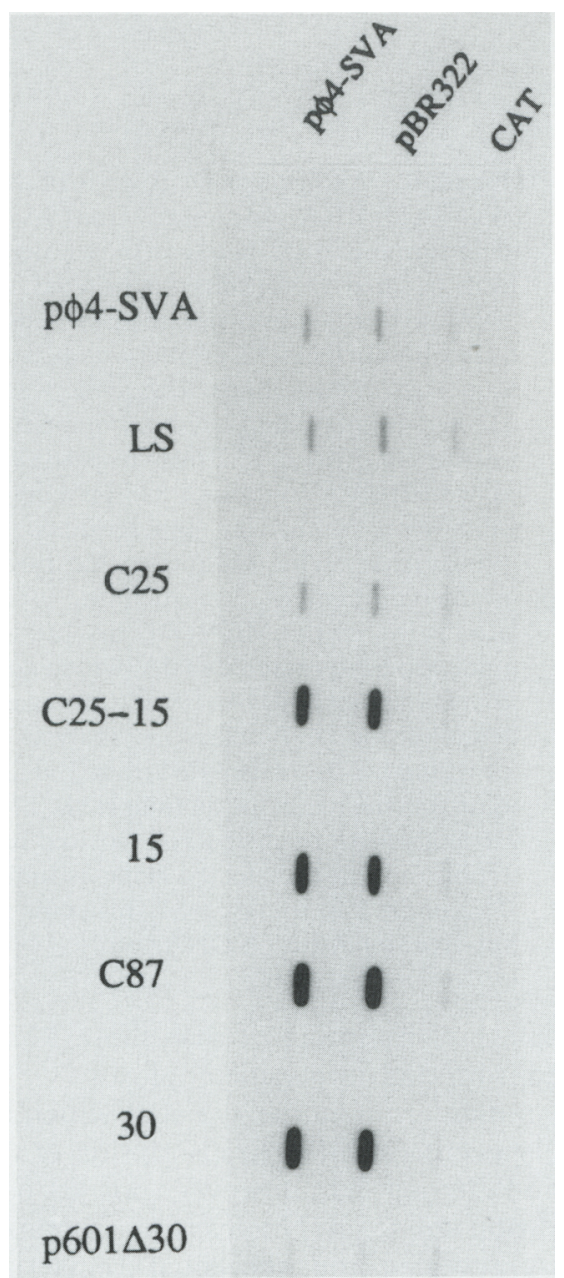

Figure 7. Nuclear transcription analysis of $3^{\prime}$ - and $5^{\prime}$-poly(A) site deletion mutants. Cells were transfected with the indicated DNAs, nuclei were isolated, and nascent RNA chains were labeled with $\left[\alpha-{ }^{32} \mathrm{P}\right] \mathrm{GTP}$. Labeled RNA $\left(1 \times 10^{7}\right) \mathrm{cpm}$ of was hybridized to excess linearized DNA bound to nitrocellulose. Horizontal rows labeled p $44-S V A$, LS, C25, C25-15, 15, C87, 30, p601-SVA $\Delta 30$ display separate filters hybridized to ${ }^{32} \mathrm{P}$-labeled RNA synthesized in nuclei isolated from cells transfected with the indicated plasmid. Nitrocellulose 'slots' in the first row contained p $\phi 4$-SVA DNA, whereas those in the second row contained pBR322 DNA; the third row contained an equivalent molar amount of a CAT gene-specific restriction fragment isolated from pSV2.CAT, as described in Materials and methods. tially random. Experiments in other systems have provided evidence consistent with each of these ideas. In the human gastrin gene it appears that termination may occur at a single site (Baek et al. 1986; Sato et al. 1986), whereas transcription of the mouse $\beta$-globin (Citron et al. 1984), dihydrofolate reductase (Frayne and Kellems 1986 ), and $\alpha$-amylase (Hagenbuchle et al. 1984) probably occurs at multiple sites located within regions of several hundred base pairs. In contrast, no specific sites of termination have been detected during transcription of the polyoma virus late strand, and it has been suggested that termination of polyoma late transcription occurs at essentially random sites (Acheson 1984). It is possible, and perhaps even likely, that these various types of terminated transcripts reflect more than one mechanism of transcription termination. In separate experiments examining transcription of the SV40 early strand in vitro in a HeLa whole-cell extract, we found that a substantial fraction of RNA polymerase molecules terminate at multiple sites in the viral origin-promoter region (Grass et al. 1987). Thus, a model for SV40 early transcription in vivo can be put forth in which termination is signaled initially by sequences at the early poly(A) addition site but does not actually occur until the polymerase has transcribed the entire viral DNA molecule, i.e., in a region approximately $2000 \mathrm{bp}$ downstream of the mRNA $3^{\prime}$ end. This model is supported by studies suggesting that the entire early DNA strand is transcribed in vivo (reviewed by Lebowitz and Weissman 1979).

How far does RNA polymerase transcribe when termination is blocked by the poly(A) site mutations? Attempts to visualize the resulting RNAs directly (by Northern blot analysis) were only partially successful, as the SV40-specific nuclear RNAs detected were of very heterogeneous size (S. Connelly, unpubl.). This could have resulted from multiple splicing events and/or limited degradation of these large abnormal RNAs. An alternative way to estimate the size of the initial primary transcripts is to compare the intensities of the bands produced by nuclease $\mathrm{S} 1$ analysis of mutant and wildtype RNA samples (e.g., Fig. 3). If, as discussed above, we assume that the wild-type template was transcribed once on average, because there was as much as 10- to 20-fold more SV40-specific RNA in cells transfected with the poly(A) site mutants, we conclude that RNA polymerase transcribed these plasmids between 10 and 20 times. Given that the size of the plasmid is $\sim 7 \mathrm{~kb}$, this leads to an estimate of the size of the primary transcript of $\sim 100 \mathrm{~kb}$. Although the transcript is obviously immense, it is of interest to note that several transcription units approximately this size (Garber et al. 1983), and possibly significantly greater (Kenwrick et al. 1987), have been described.

How do sequences at the poly(A) site signal transcription termination? Bearing in mind that termination actually occurs a considerable distance downstream of this site, we suggest two possible models. In one, the DNA sequences themselves might signal termination. This could be envisioned to occur in at least two ways. First, the nucleotide sequence in this region, or perhaps an al- 
tered DNA structure (Muller et al. 1987), might be recognized by the polymerase so that its ability to elongate efficiently would be impaired. This could result from a conformational change in the enzyme, or from the loss of a subunit. Second, the polymerase could become elongation inefficient by interaction with a protein bound to this region of the DNA. For example, we note that the GT-rich sequence is a perfect match with the enhancer 'core' consensus sequence (Weiher et al. 1983). As nuclear proteins that bind to this sequence have been identified (e.g. Johnson et al. 1987; Piette and Yaniv 1987; Rosales et al. 1987; Xiao et al. 1987); it may be that such a protein binds to the GT-rich poly(A) site sequence and interacts with RNA polymerase in a way that causes it to become elongation incompetent.

Although the proposal that DNA sequences signal termination is attractive in some respects, we favor the view that it is the act of RNA cleavage/polyadenylation itself that leads eventually to transcription termination, for the following reason. Our results indicate that not only the GT-rich sequence but also one of the two AATAAA sequences are required for termination. From the studies presented here and previously (Hart et al. 1985; Kessler et al. 1986), these are precisely the same sequences that are required for efficient mRNA 3 '-end formation. Thus, we believe the simplest model is that the occurrence of cleavage/polyadenylation is in some manner signaled to the elongating RNA polymerase, resulting in termination. This requires that $3^{\prime}$-end processing of the pre-mRNA occurs on nascent chains. This question has been addressed in the case of the adenovirus late transcription unit, where it appears that cleavage/polyadenylation does indeed take place on nascent RNA chains (Nevins and Darnell 1978; Manley et al. 1982).

How mechanistically might cleavage of the premRNA signal termination? One interesting possibility, indicated diagrammatically in Figure 8, is that following cleavage, the downstream RNA product is degraded by a $5^{\prime}$ to $3^{\prime}$ exonuclease which, upon reaching the elongating RNA polymerase, perhaps at a specific pause site, signals the enzyme to terminate. Several observations are consistent with this idea. First, RNA sequences downstream of poly(A) sites have been shown to be extremely unstable in vivo (Berget and Sharp 1979), in isolated nuclei (Manley et al. 1979, 1982), and in vitro (Moore and Sharp 1985; Zarkower et al. 1986). Second, these sequences can be degraded as nascent chains (Manley et al. 1982). Third, we have detected and characterized a $5^{\prime}$ to $3^{\prime}$ exonuclease that degrades uncapped RNAs efficiently, including the downstream product of cleavage and polyadenylation, in HeLa nuclear extracts (Noble et al. 1986; Ryner and Manley 1987; P. Park, unpubl.). Finally, we wish to point out that in several respects, this proposed mechanism is analogous to $p$-factor mediated transcription termination in Escherichia coli (reviewed by Platt 1986). In this system, it appears that a protein ( $\rho$-factor) recognizes nascent RNA in a region upstream of the actual termination site, and, in a reaction dependent on ATP hydrolysis, migrates along the

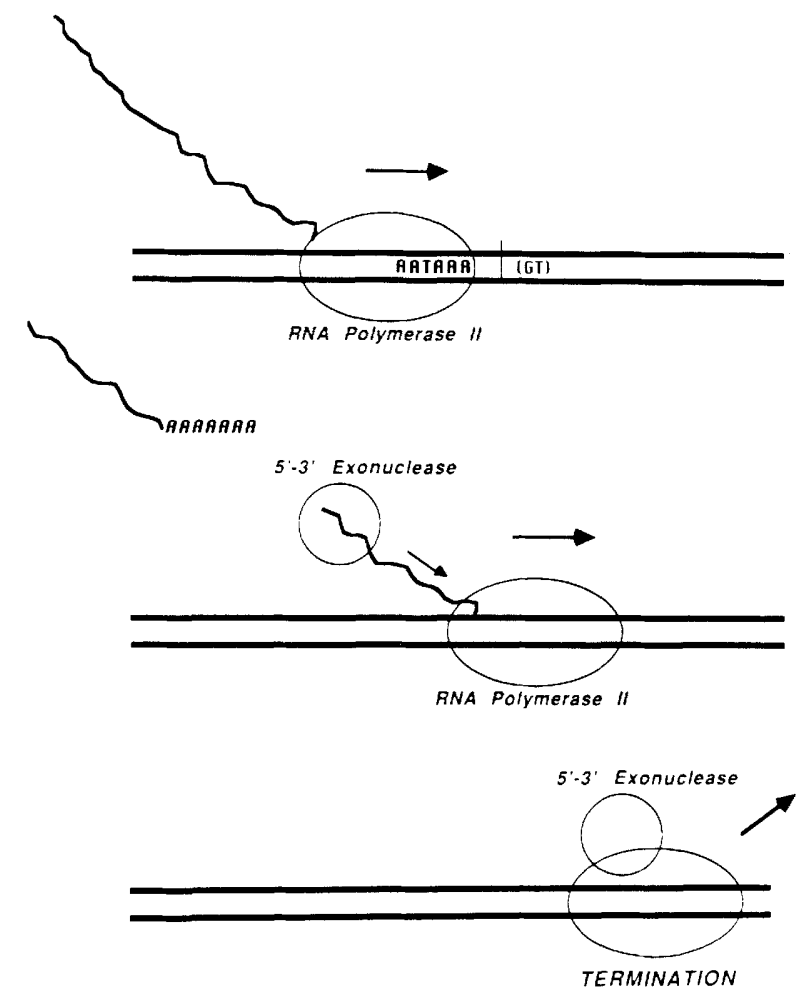

Figure 8. A model for coupling pre-mRNA $3^{\prime}$-end formation to transcription termination. The double line depicts the DNA template; the oval, RNA polymerase II; and the wavy line, the RNA transcript. The AATAAA and GT-rich regions are indicated, and the cleavage/polyadenylation site is represented by the thin vertical line between these two sequences. Following cleavage of the nascent RNA, the downstream RNA product is degraded by a $5^{\prime}$ - to $3^{\prime}$-exonuclease which, upon reaching the elongating polymerase, signals transcription termination.

RNA, leading to termination when the factor encounters the paused RNA polymerase. The $5^{\prime}$ to $3^{\prime}$ exonuclease might then serve a function similar to the prokaryotic $\rho$-factor. Reproduction of the termination reaction in vitro will be required to elucidate the actual mechanism.

\section{Materials and methods}

Plasmids

The plasmid p $\phi 4$-SVA (Manley 1983; Lewis and Manley 1985) contains adenoviral major late promoter sequences from -405 to +33 relative to the transcription start site $(+1)$ joined to an SV40 DNA segment extending from a HindIII site at SV40 nucleotide 5171 to the BamHI site at nucleotide 2533 (Tooze

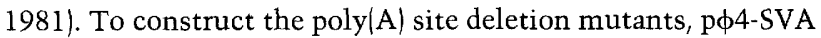
was linearized with either BamHI or BclI (nucleotide 2770) and digested with $B a l 31$ exonuclease. Wild-type sequences were reconstructed upstream of the BcII site in the $5^{\prime}$ mutants. Details of deletion mutant construction have been published previously (Manley et al. 1985). In addition, the pBR322 sequences flanking the BamHI-generated mutations were also reconstructed so that the same pBR322 sequences abut the deletion endpoints. This was accomplished by inserting BstXI (SV40 nucleotide 4759|-BamHI fragments from the appropriate mutants into the BstXI-BamHI sites of p $\phi 4$-SVA. p601-SVA $\Delta 30$ was 
constructed in an analogous manner. The substitution mutant LS was constructed by inserting a Sau3A fragment (nucleotides 2534-2771) from the $5^{\prime}$-deletion mutant C87 into the BamHI site of the 3'-deletion mutant 20 , thereby deleting nucleotides 2619-2610, which contain the $3^{\prime}$-AATAAA sequence, and replacing them with the sequence GGATCA. The sequence of the resulting mutant was verified by nucleotide sequence analysis (Maxam and Gilbert 1980). The double mutant C25-15 was constructed in an analogous manner by joining the appropriate sequences from the 3 '-deletion mutant 15 with the 5 '-deletion mutant C25, thereby deleting SV40 nucleotides 2579-2533 and $2770-2622$.

\section{Cell culture and transfection}

Type 293 cells were grown in Dulbecco's modified Eagle's medium supplemented with $10 \%$ fetal bovine serum (GIBCO). For transfection, $\sim 1.8 \times 10^{6}$ cells were plated $24 \mathrm{hr}$ before addition of the DNA precipitate. Cell transfection was carried out as described (Lewis and Manley 1985), except that $30 \mu \mathrm{g}$ of DNA, consisting of $27 \mu \mathrm{g}$ of the relevant plasmid DNA and $3 \mu \mathrm{g}$ of pSV2.CAT DNA (Gorman et al. 1982), was used. Transfection efficiencies were standardized by quantitating the amount of chloramphenical acetyltransferase (CAT) activity present in cell lysates. Cells were harvested $48 \mathrm{hr}$ after transfection and resuspended in TSM [10 mM Tris (pH 7.4), $0.15 \mathrm{M} \mathrm{NaCl}, 3 \mathrm{~mm}$ $\mathrm{MgCl}_{2}$ ]. Fifteen percent of each cell suspension was removed and used to determine CAT activities by the method of Gorman et al. (1982). Protein concentrations of cell lysates were measured, and equal amounts of protein were added to each enzyme assay. ${ }^{14} \mathrm{C}$-labeled chloramphenicol (New England Nuclear) and the mono- and diacetylated forms of chloroam phenicol were separated by silica gel thin-layer chromatography. The reaction products, visualized by autoradiography, were scraped from the plate and quantitated by scintillation counting. Transfection efficiencies were found to vary by, at most, twofold.

\section{RNA extraction and analysis}

RNA was extracted from the cytoplasm (Lewis and Manley 1985), nucleus (Maniatis et al. 1982), or the whole cell (Maniatis et al. 1982). Aliquots were selected on oligo(dT)-cellulose (Aviv and Leder 1972), where indicated. RNAs were analyzed by nuclease S1 analysis, as described (Berk and Sharp 1977), with the following exceptions: A standardized concentration, based on the results of CAT enzyme assays (see above) of the indicated RNA (30 $\mu \mathrm{g}$ or less) was hybridized to $2 \mathrm{ng}$ of the appropriate probe. The 3 '-ends of SV40-specific RNAs were analyzed by hybridization to single-stranded 3 '-end-labeled DNA probes labeled with T4 DNA polymerase and $\left[\alpha^{-32} \mathrm{P}\right] \mathrm{dXTPs}$ and strand separated according to standard procedures (Maniatis et al. 1982). Hybridization was carried out at $45^{\circ} \mathrm{C}$ for $12 \mathrm{hr}$, and the hybrids were digested on ice for $30 \mathrm{~min}$ with $500 \mathrm{U} / \mathrm{ml}$ of nuclease S1 (Sigma). Hybridization using the probe derived from C25 DNA was carried out at $37^{\circ} \mathrm{C}$ for $6 \mathrm{hr}$, and the hybrids were digested at $37^{\circ} \mathrm{C}$ for $30 \mathrm{~min}$ with $150 \mathrm{U} / \mathrm{ml}$ of nuclease $\mathrm{S} 1$. Determination of the $5^{\prime}$-ends of these RNAs was performed by nuclease $\mathrm{Sl}$ analysis using a double-stranded $5^{\prime}$-end-labeled DNA probe, as described (Lewis and Manley 1985). All nuclease SI digestion products were electrophoresed through $8 \%$ polyacrylamide- $8 \mathrm{M}$ urea sequencing-type gels (Maxam and Gilbert 1980|. Autoradiographic exposures shown were obtained with intensifying screens, although exposures for densitometer scanning were produced without the use of screens.

\section{In vitro nuclear transcription analysis}

Nuclei were purified $48 \mathrm{hr}$ after transfection essentially by the method of Salditt-Georgieff et al. (1984). Briefly, cells were harvested and washed in TSM, and nuclei were isolated by centrifugation following lysis of cells in TSM plus $0.5 \%$ Triton X-100. Nuclei were washed two times in TSM plus $0.1 \%$ Triton X-100, resuspended in an equal volume of storage buffer $[50 \mathrm{~mm}$ Tris (pH 7.9), $5 \mathrm{~mm} \mathrm{MgCl}_{2}, 0.1 \mathrm{~mm}$ EDTA, $1 \mathrm{~mm}$ dithiothreitol (DTT), 30\% glycerol], quick frozen and stored at $-80^{\circ} \mathrm{C}$. All nuclei used in transcription reactions were from cells that showed identical transfection efficiencies, measured as described above. To label nascent RNA chains, nuclei were thawed and mixed with an equal volume of $2 \times$ reaction buffer [1 mM ATP, UTP, CTP, $5 \mathrm{~mm} \mathrm{MgCl} 2,300 \mathrm{~mm} \mathrm{KCl}, 10 \mathrm{~mm}$ Tris (pH 7.9)] plus $100 \mu \mathrm{Ci}\left[\alpha^{-32} \mathrm{P} \mid \mathrm{GTP}\right.$ (3000 Ci/mmole). Where indicated, $\alpha$-amanitin was added to a final concentration of 1 $\mu \mathrm{g} / \mathrm{ml}$. Transcription reactions were carried out at $30^{\circ} \mathrm{C}$ for 30 min, although similar results were obtained from $10-\mathrm{min}$ incubations. Reactions were terminated by the addition of an equal volume of $2 \times \mathrm{HSB}$ [20 mM Tris $(\mathrm{pH} 7.4), 1 \mathrm{M} \mathrm{NaCl}, 20 \mathrm{~mm}$ $\mathrm{MgCl}_{2}$ ] and $50 \mu \mathrm{g} / \mathrm{ml}$ RNase-free DNase (Cooper) and incubated at $25^{\circ} \mathrm{C}$ for an additional $15 \mathrm{~min}$. RNA was purified essentially by the method of Triesman and Maniatis (1982) and ethanol precipitated from $1 \mathrm{M} \mathrm{NH}_{4} \mathrm{Ac}$ an additional three times to remove unincorporated $\left[\alpha^{-32} \mathrm{P}\right] \mathrm{GTP}$.

Four micrograms of linearized p $\phi 4$-SVA, pBR322 DNA, or the equivalent molar amount of a pSV2.CAT restriction fragment, extending from a ScaI (pSV2.CAT nucleotide 4353) to a HindIII (pSV2.CAT nucleotide 5020) site, were denatured and bound to nitrocellulose essentially by the method of Salditt-Georgieff et al. (1984), using a 'hybrislot' manifold (Bethesda Research Laboratories). Prehybridization of filters was done at $65^{\circ} \mathrm{C}$ for $3-6 \mathrm{hr}$ in prehybridization buffer [50 mM HEPES (pH 7.4), $0.3 \mathrm{M} \mathrm{NaCl}$, $10 \mathrm{mM}$ EDTA, $1 \mathrm{mg} / \mathrm{ml}$ yeast tRNA, $0.5 \mathrm{mg} / \mathrm{ml}$ poly(A), $1 \%$ Na-pyrophosphate|. Alkali breakage of RNA was performed according to the technique of Hofer and Darnell (1981). Filters were washed briefly with hybridization buffer $[50 \mathrm{mM}$ HEPES (pH 7.4), $0.3 \mathrm{M} \mathrm{NaCl}, 10 \mathrm{~mm}$ EDTA, $0.2 \%$ SDS, $0.1 \mathrm{mg} / \mathrm{ml}$ tRNA, $0.1 \mathrm{mg} / \mathrm{ml}$ poly $(\mathrm{A}), 0.1 \% \mathrm{Na}$-pyrophosphate], and hybridized in $0.5 \mathrm{ml}$ of hybridization buffer containing $\sim 1 \times 10^{7}$ cpm RNA for $36 \mathrm{hr}$ at $65^{\circ} \mathrm{C}$. After hybridization, the filters were washed for $30 \mathrm{~min}$ at $65^{\circ} \mathrm{C}$ with $2 \times \mathrm{SSC}, 30 \mathrm{~min}$ at $37^{\circ} \mathrm{C}$ with $2 \times$ SSC plus $10 \mu \mathrm{g} / \mathrm{ml}$ pancreatic RNase, and $30 \mathrm{~min}$ at $37^{\circ} \mathrm{C}$ with $2 \times$ SSC. Filters were air-dried and exposed to X-ray film for $12-36 \mathrm{hr}$.

\section{Acknowledgments}

We thank L. Ryner, J. Noble, X.-Y. Fu, and especially Y. Takagaki for constructive discussions and $\mathrm{L}$. Ryner for comments on the manuscript. We are grateful to K. Harding for help with the photography. We also thank W. Ehrman and M. Kopczynski for excellent technical assistance and $\mathrm{W}$. Weast for typing the manuscript. This work was supported by U.S. Public Health Service grant GM-28983 from the National Institutes of Health.

\section{References}

Acheson, N.M. 1984. Kinetics and efficiency of polyadenylation of late polyoma-virus nuclear RNA: Generation of oligomeric polyadenylated RNAs and their processing into mRNA. Mol. Cell. Biol. 4: 722-729.

Aiello, L., R. Guilfoyle, K. Huebner, and R. Weinmann. 1979. Adenovirus 5 -DNA sequences present and RNA sequences 
transcribed in transformed human embryo kidney cells (HEK-Ad5 or 293). Virology 94: 460-469.

Amara, S.G., R.M. Evans, and M.G. Rosenfeld. 1984. Calcitonin/calcitonin gene-related peptide transcription unit: Tissue-specific expression involves selective use of alternative polyadenylation sites. Mol. Cell. Biol. 4: 2151-2160.

Aviv, H. and P. Leder. 1972. Purification of biologically active globin messenger RNA by chromatography on oligothymidylic acid-cellulose. Proc. Natl. Acad. Sci. 69: 1408-1412.

Baek, K.-H., K. Sato, R. Ito, and K. Agerwal. 1986. RNA polymerase II transcription terminates at a specific DNA sequence in a HeLa cell-free reaction. Proc. Natl. Acad. Sci. 83: 7623-7627.

Berget, S.M. 1984. Are U4 small nuclear ribonucleoproteins involved in polyadenylation? Nature 309: 179-182.

Berget, S.M. and P.A. Sharp. 1979. Structure of the late adenovirus 2 heterogeneous nuclear RNA. I. Mol. Biol. 129: 547565.

Berk, A.J. and P.A. Sharp. 1977. Sizing and mapping of early adenovirus mRNAs by gel electrophoresis of $\mathrm{S} 1$ endonuclease-digested hybrids. Cell 12: 721-732.

Birnsteil, M.L., M. Busslinger, and K. Strub. (1985). The end is in site Cell 41: 349-359.

Citron, B., E. Falck-Pedersen, M. Salditt-Georgieff, and J.E. Darnell, Jr. 1984. Transcription termination occurs within a $1000 \mathrm{bp}$ region downstream of the poly(A) site of the mouse B-globin (major) gene. Nucleic Acids Res. 12: 8723-8731.

Falck-Pedersen, E., J. Logan, T. Shenk, and J.E. Darnell, Jr. 1985. Transcription termination within the E1A gene of adenovirus induced by insertion of the mouse -major $\beta$-globin terminator element. Cell 40: 897-905.

Fitzgerald, M. and T. Shenk. 1981. The sequence 5'-AAUAAA$3^{\prime}$ - forms part of the recognition site for polyadenylation of late SV40 mRNAs. Cell 24: 251-260.

Ford, J.P. and M.-T. Hsu. 1978. Transcription pattern of in vivo labeled late simian virus 40 RNA: Equimolar transcription beyond the mRNA 3'- terminus. J. Virol. 28: 795-801.

Frayne, E.G. and R.E. Kellems. 1986. Structural features of the murine dihydrofolate reductase transcription termination region: Identification of a conserved DNA sequence element. Nucleic Acids Res. 14: 4113-4125.

Frayne, E.G., E.J. Leys, G.F. Crouse, A.G. Hook, and R.E. Kellems. 1984. Transcription of the mouse dihydrofolate reductase gene proceeds unabated through seven polyadenylation sites and terminates near a region of repeated DNA. Mol. Cell.Biol. 4: 2921-2924.

Garber, G.L., A. Kuroiwa, and W.J. Gehring. 1983. Genomic and cDNA clones of the homeotic locus Antennapedia in Drosophila. EMBO J. 2: 2027-2036.

Gluzman, Y. 1981. SV40-transformed simian cells support the replication of early SV40 mutants. Cell 23: 175-182.

Gorman, C.M., L.F. Moffat, and B.H. Howard. 1982. Recombinant genomes which express chloramphenicol acetyl transferase in mammalian cells. Mol. Cell. Biol. 2: 1044-1051.

Graham, F.L., I. Smiley, W.C. Russell, and R. Nairn. 1977. Characterization of human cell line transformed by DNA from human adenovirus type 5. J. Gen. Virol. 36: 59-72.

Grass, D., R. Jove, and J.L. Manley. 1987. RNA polymerase II terminates transcription in vitro in the SV40 origin region. Nucleic Acids Res. 15: 4417-4436.

Hagenbuchle, O., P.K. Wellaver, D.L. Cribbs, D.L., and U. Schibler. 1984. Termination of transcription in the mouse $\alpha$-amylase gene Amy-2 $2^{a}$ occurs at multiple sites downstream of the polyadenylation site. Cell 38: 737-744.

Hart, R.P., M.A. McDevitt, H. Ali, and J.R. Nevins. 1985. Definition of essential sequences and functional equivalence of elements downstream of the adenovirus E2A and early simian virus 40 polyadenylation sites. Mol. Cell. Biol. 5: $2975-2983$.

Higgs, D.R., S.V.E. Goodbourn, J. Lamb, J.B. Clegg, D.J. Weatherall, and N.J. Proudfoot. 1983. Alpha-thalessemia caused by a polyadenylation signal mutation. Nature 306: 398 -400 .

Hofer, E. and J.E. Darnell, Jr. 1981. The primary transcription unit of the mouse $\beta$-major globin gene. Cell 23: 585-593.

Hofer, E., R. Hofer-Warbinek, and J.E. Darnell, Jr. 1982. Globin RNA transcription: A possible termination site and demonstration of transcriptional control correlated with altered chromatin structure. Cell 29: 887-893.

Johnson, P.F., W.H. Landschulz, B.J. Graves, B.J., and S.L. McKnight. 1987. Identification of a rat liver nuclear protein that binds to the enhancer core element of three animal viruses. Genes Dev. 1: 133-146.

Kenwrick, S., M. Patterson, A. Speer, K. Fishbeck, and K. Davies. 1987. Molecular analysis of the Duchenne muscular dystrophy region using pulsed field gel electrophoresis. Cell 48:351-357.

Kessler, M.M., R.C. Beckendorf, M.A. Westhafer, and J.L. Nordstrom. 1986. Requirement of A-A-U-A-A-A and adjacent downstream sequences for SV40 early polyadenylation. $\mathrm{Nu}$ cleic Acids Res. 14: 4939-4952.

Lebowitz, P. and S.M. Weisman. 1979. Organization and transcription of the simian virus 40 genome. Curr. Top. Microbiol. Immunol. 87: 43-172.

LeMeur, M.A., B. Galliot, and P. Gerlinger. 1984. Termination of the ovalbumin gene transcription. EMBO J. 3:27792786.

Lewis, E.D. and J.L. Manley. 1985. Control of adenovirus late promoter expression in two human cell lines. Mol. Cell. Biol. 5: 2433-2442.

Logan, J., E. Falk-Pederson, J.E. Darnell, and T. Shenk. 1987. A poly(A) addition site and a downstream termination region are required for efficient cessation of transcription by RNA polymerase II in the mouse $\beta$-globin gene. Proc. Natl. Acad. Sci. 84: 8306-8310.

Maniatis, T.E., E.F. Fritsch, and J. Sambrook. 1982. Molecular cloning: A laboratory manual. Cold Spring Harbor Laboratory, Cold Spring Harbor, New York.

Manley, J.L. 1983. Accurate and specific polyadenylation of mRNA precursors in a soluble whole-cell lysate. Cell 33: 595-605.

Manley, J.L., P.A. Sharp, and M.L. Gefter. 1979. RNA synthesis in isolated nuclei: In vitro initiation of adenovirus 2 major late mRNA precursor. Proc. Natl. Acad. Sci. 76: 160-164.

- 1982. RNA synthesis in isolated nuclei: Processing of adenovirus serotype 2 late messenger RNA precursors. I. Mol. Biol. 159: 581-599.

Manley, J.L., H. Yu, and L. Ryner. 1985. RNA sequence containing hexanucleotide AAUAAA directs efficient mRNA polyadenylation in vitro. Mol. Cell. Biol. 5: 1347-1368.

Montell, C.E., E.J. Fisher, M.H. Caruthers, and A.J. Berk. 1983. Inhibition of RNA cleavage but not polyadenylation by a point mutation in mRNA 3 '-consensus sequence AAUAAA. Nature 305: 600-605.

Moore, C.L., M. Skolnik-David, and P.A. Sharp. 1986. Analysis of RNA cleavage at the adenovirus- 2 L3 polyadenylation site. $E M B O$ I. 5: 1929-1938.

Moore, C.L. and P.A. Sharp. 1985. Accurate cleavage and polyadenylation of exogenous RNA substrate. Cell 41: 845-885.

Muller, B.C., A.L. Raphael, and J.K. Barton. 1987. Evidence for altered DNA conformations in the simian virus 40 genome: Site-specific DNA cleavage by the chiral complex $\Lambda$-tris 14 , 
7-diphenyl-1, 10-phenanthrolinelcobalt (III). Proc. Natl. Acad. Sci. 84: 1764-1768.

Nevins, J.R. and J.E. Darnell, Jr. 1978. Steps in the processing of Ad2 RNA: Poly $(A)^{+}$nuclear sequences are conserved and poly(A) addition precedes splicing. Cell 15: 1477-1493.

Noble, J.C.S., C. Prives, and J.L. Manley. 1986. In vitro splicing of simian virus 40 early pre mRNA. Nucleic Acids Res. 14: $1219-1235$.

Piette, J. and M. Yaniv. 1987. Two different factors bind to the $\alpha$-domain of the polyoma virus enhancer, one of which also interacts with the SV40 and c-fos enhancers. EMBO $I$. 6: $1331-1337$

Platt, T. 1986. Transcription termination and regulation of gene expression. Annu. Rev. Biochem. 55: 339-372.

Proudfoot, N.J. and G.G. Brownlee. 1976. 3'- non-coding region sequences in eukaryotic mRNA. Nature 263: 211-214.

Rosales, R., M. Vigneron, M. Machi, I. Davidson, J.H. Xiao, and P. Chambon. 1987. In vitro binding of cell specific and ubiquitous nuclear proteins to the octoner motif of the SV40 enhancer and related motifs present in other promoters and enhancers. EMBO \%. 6: 3015-3025.

Ryner, L.C. and J.L. Manley. 1987. Requirements for accurate and efficient mRNA $3^{\prime}$ - end cleavage and polyadenylation of a simian virus 40 early pre-RNA in vitro. Mol. Cell. Biol. 7: 495-503.

Sadofsky, M., S. Connelly, J.L. Manley, and J.C. Alwine. 1985. Identification of a sequence element on the $3^{\prime}$-side of AAUAAA which is necessary for simian virus 40 late mRNA $3^{\prime}$-end processing. Mol. Cell Biol. 5: 2713-2719.

Salditt-Georgieff, M., M. Sheffrey, K. Krauter, J.E. Darnell, R. Rifkind, and P.A. Marks. 1984. Induced transcription of the mouse $\beta$-globin transcription unit in erythroleukemia cells: Time-course of induction and of changes in chromatin structure. 1. Mol. Biol. 172: 437-450.

Sato, K., R. Ito, K.-H. Baek, and K. Agarwal. 1986. A specific DNA sequence controls termination of transcription in the gastrin gene. Mol. Cell. Biol. 6: 1032-1043.

Sheets, M.D., P. Stephenson, and M.P. Wickens. 1987. Products of in vitro cleavage and polyadenylation of simian virus 40 late pre-mRNAs. Mol. Cell. Biol. 7: 1518-1529.

Sheffy, M., P.A. Marks, and R.A. Rifkind. 1984. Gene expression in murine erythroleukemia cells: Transcriptional control and chromatin structure of the $\alpha_{1}$ globin gene. I. Mol. Biol. 172: 417-436.

Tooze, J. 1981. DNA tumor viruses, 2nd ed. Cold Spring Harbor Laboratory, Cold Spring Harbor, New York.

Treisman, R. and T. Maniatis. 1982. Simian virus 40 enhancer increases number of RNA polymerase II molecules on linked DNA. Nature 315: 72-75.

Weber, J., W. Jelinek, and J.E. Darnell, Jr. 1977. The definition of a large viral transcription unit late in Ad2 infection of HeLa cells: Mapping of nascent RNA molecules labeled in isolated nuclei. Cell 10: 611-616.

Weiher, H., M. Konig, and P. Gruss. 1983. Multiple point mutations affecting the simian virus 40 enhancer. Science 219:626-631.

Weintraub, M., A. Larsen, and M. Groudine. 1981. $\alpha$-Globingene switching during the development of chicken embryos: Expression and chromosome structure. Cell 24: 333-344.

Whitelaw, E. and N. Proudfoot. 1986. $\alpha$-Thallassaemia caused by a poly(A) site mutation reveals that transcriptional termination is linked to $3^{\prime}$ - end processing in the human $\alpha-2$ globin gene. $E M B O$ I. 5: 2915-2922.

Wickens, M. and P. Stephenson. 1984. Role of the conserved AAUAAA sequence: Four AAUAAA point mutants prevent messenger RNA 3'- end formation. Science 226: 1045-1051.
Xiao, J.-H., I. Davidson, M. Macchi, R. Rosales, M. Vigneron, A. Staub, and P. Chambon. 1987. In vitro binding of several cell-specific and ubiquitous nuclear proteins to the GT-I motif of the SV40 enhancer. Genes Dev. 1: 794-807.

Zarkower, D., P. Stephenson, M. Sheets, and M. Wickens. 1986. The AAUAAA sequence is required for polyadenylation of simian virus 40 pre-mRNA in vitro. Mol. Cell. Biol. 6: $2317-2323$. 


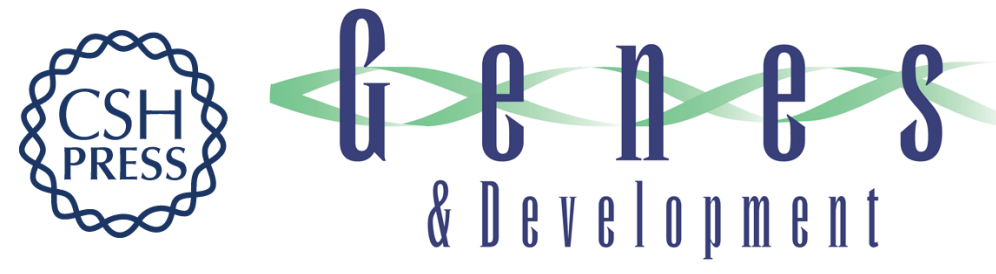

\section{A functional mRNA polyadenylation signal is required for transcription termination by RNA polymerase II.}

S Connelly and J L Manley

Genes Dev. 1988, 2:

Access the most recent version at doi:10.1101/gad.2.4.440

References This article cites 60 articles, 21 of which can be accessed free at:

http://genesdev.cshlp.org/content/2/4/440.full.html\#ref-list-1

License

Email Alerting

Service

Receive free email alerts when new articles cite this article - sign up in the box at the top right corner of the article or click here.

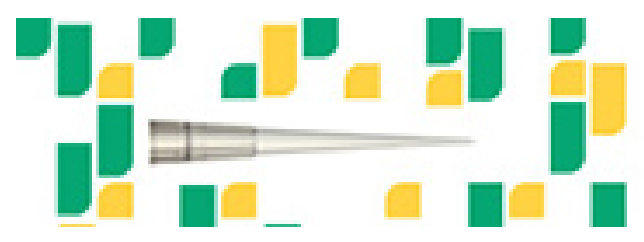

Focused on your science.

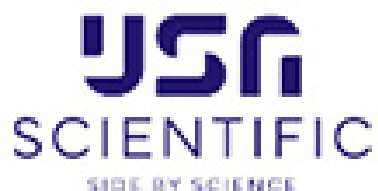

Copyright (c) Cold Spring Harbor Laboratory Press 